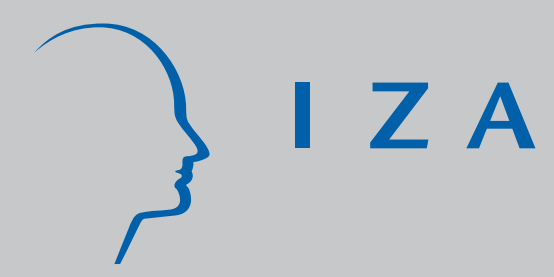

IZA DP No. 3730

Tournaments and Managerial Incentives in China's Listed Firms: New Evidence

\author{
Takao Kato
}

Cheryl Long

September 2008 


\title{
Tournaments and Managerial Incentives in China's Listed Firms: New Evidence
}

\author{
Takao Kato \\ Colgate University, Columbia Business School, \\ University of Tokyo, Aarhus School of Business and IZA \\ Cheryl Long \\ Colgate University and UESTC
}

Discussion Paper No. 3730

September 2008

IZA

P.O. Box 7240

53072 Bonn

Germany

Phone: $+49-228-3894-0$

Fax: +49-228-3894-180

E-mail: iza@iza.org

\begin{abstract}
Any opinions expressed here are those of the author(s) and not those of IZA. Research published in this series may include views on policy, but the institute itself takes no institutional policy positions.

The Institute for the Study of Labor (IZA) in Bonn is a local and virtual international research center and a place of communication between science, politics and business. IZA is an independent nonprofit organization supported by Deutsche Post World Net. The center is associated with the University of Bonn and offers a stimulating research environment through its international network, workshops and conferences, data service, project support, research visits and doctoral program. IZA engages in (i) original and internationally competitive research in all fields of labor economics, (ii) development of policy concepts, and (iii) dissemination of research results and concepts to the interested public.
\end{abstract}

IZA Discussion Papers often represent preliminary work and are circulated to encourage discussion. Citation of such a paper should account for its provisional character. A revised version may be available directly from the author. 
IZA Discussion Paper No. 3730

September 2008

\section{ABSTRACT}

\section{Tournaments and Managerial Incentives in China's Listed Firms: New Evidence}

The promotion tournament as a potentially important incentive mechanism for top management in transition economies has not been examined by the emerging literature on managerial incentives in transition economies. This paper is the first attempt to fill this important gap in the literature. The paper begins with modifying the previously-derived empirical predictions from the tournament theory to the context of transition economies in which state ownership still plays a significant role in publicly-traded firms. Specifically, we test the following two hypotheses. First, the winner's prize will need to increase in order to prevent each contestant from lowering his/her effort level in the face of expanding contestant pool. Such an optimal response of the winner's prize to the size of the contestant pool is more evident for China's listed firms that are less controlled by the state. Second, the winner's prize will also need to rise in order to prevent each contestant from reducing his/her effort level in the face of greater market volatility (or more noise in performance measure used to decide on the tournament winner). Using comprehensive financial and accounting data on China's listed firms from 1998 to 2002, augmented by unique data on executive compensation and ownership structure, we find evidence in support of both hypotheses. Finally, we also find evidence suggesting that an increase in the winner's prize will result in enhanced managerial effort and hence improved firm performance, and that the performance effect of the winner's prize is greater for China's listed firms that are less controlled by the state. As such this paper provides yet another piece of evidence that ownership restructuring may be needed for China to successfully transform its SOEs to efficient modernized corporations and reform its overall economy.

JEL Classification: M51, P3

Keywords: tournaments, managerial incentives, ownership structure, China, transition economies

Corresponding author:

Takao Kato

Department of Economics (Persson 222)

Colgate University

13 Oak Drive

Hamilton, NY 13346

USA

E-mail: tkato@mail.colgate.edu

\footnotetext{
* This research was funded by grants from the ABDI (Asian Development Bank Institute) and the Asian Studies program of Colgate University, as well as a Picker Research Fellowship from the Research Council of Colgate University. Kevin J. Murphy, Runtian Jing, and Jan Svejnar provided us with advice and encouragement on our research program on managerial incentives in China in general. The paper also benefited from comments and suggestions at the Tournaments, Contests and Relative Performance Evaluation conference at North Carolina State University in Raleigh, NC, USA, on March 8-9, 2008. The data used in the paper are provided by Shenzhen GuoTaiAn IT Co. and SinoFin Inc. We are grateful for support from these individuals and organizations.
} 


\section{Tournaments and Managerial Incentives in China's Listed Firms: New Evidence}

\section{$\underline{\text { I. Introduction }}$}

Theorists have identified several matters concerning the managerial labor market that potentially have a vital bearing on the success of overall reform during transition (e.g. Aghion et al., 1994). Key issues include the formation of markets for managers and the specific design of management contracts in order to contribute to improved incentive packages for managers and ultimately to result in improved enterprise productivity.

To address such key issues facing transition economies, prior studies focus on two main incentive mechanisms for top management: (i) pay-performance sensitivities (linking executive pay to firm performance); and (ii) turnover-performance sensitivities (making the probability of top management dismissal more sensitive to firm performance). Jones and Kato (1996) draw on panel survey data for a large sample of Bulgarian firms to report some of the first econometric evidence on the determinants of executive compensation for an economy during fading communism and early transition. Using standard specifications, the level of CEO pay was found to be positively related to size but not to profitability. In specifications adapted to transitional economies, the level of CEO compensation was found to be positively related to size and to productivity and to be more strongly tied to productivity when the firm was either corporatized or privatized. More recent studies examine such pay-performance link for top management in other transitional economies, including Jones and Mygind (2004) for Estonia; Eriksson (2005) for Czech and Slovak Republics; and Kato and Long (2006a) for China. In addition, several attempts have been made recently to estimate the sensitivities of CEO turnover to firm performance in transition economies (Eriksson, 2005 for Czech and Slovak Republics; Muravyev, 2003 for Russia; and Kato and Long, 2006b and 2006c for China). 
The literature on top management incentives in developed countries, however, points out that there is another potentially powerful incentive mechanism for top managers, i.e., promotion tournament. Nonetheless, the promotion tournament as a potentially important incentive mechanism for top management in transition economies has not been examined by the emerging literature on managerial incentives in transition economies. This paper is the first attempt to fill this important gap in the literature. Specifically, we use financial, personnel, and ownership information at firm level and test in the context of Chinese listed firms the empirical validity of the tournament theory developed originally by Lazear and Rosen (1981). Following the relatively small empirical literature on tournaments, all of which use data from firms in developed countries (see, for instance, O'Reilly and et. al., 1988, Ehrenberg and Bognanno, 1990, Main, and et. al., 1993, Lambert and et. al., 1993, Baker and et. al., 1994, Knoeber and Thurman, 1995, Drago and Garvey, 1998, Eriksson, 1999, Bognanno, 2001, Agrawal and et., al., 2004, and Audas, 2004), we begin with two previously-tested empirical predictions from the tournament model: (i) the prize of the tournament (the salary gap between the top executive and the other contestants) rises with the number of contestants in the tournament pool; and (ii) the prize of the tournament is greater in firms facing more volatile market conditions (and hence managers having less control over their performance). ${ }^{1}$

We then examine the effect of ownership structure on the sensitivities of the tournament prize to the size of the contestant pool and market volatility. Our OLS estimates show that the sensitivities of the tournament prize to the size of the contestant pool and market volatility are significantly greater for firms that are less state-owned, pointing to the limited relevance of the tournament model to China's listed firms with greater ownership of the state. It follows that state

\footnotetext{
${ }^{1}$ There is an important and growing experimental literature on tournaments. Since we use nonexperimental data, we draw mostly on the empirical literature on tournaments.
} 
ownership may hinder the use of tournament as an incentive mechanism for top management in China's listed firms. Recent studies on the sensitivities of top management pay and turnover to firm performance in China's listed firms also point to the absence or weak presence of the more standard incentive mechanisms for top management (linking pay and turnover to firm performance) in listed firms that are still state-controlled (Kato and Long, 2006a and 2006b). ${ }^{2}$ As such, our new finding on the relevance of the tournament model to China's listed firms with varying degrees of state ownership and control provides yet another piece of evidence for the importance of ownership restructuring in China's current effort to create modern and efficient corporations with high quality corporate governance and adequate incentives for top management.

Finally, to see if a higher prize actually results in enhanced managerial effort and hence improved firm performance, we estimate the effect on firm performance of the winner's prize for firms with differing levels of state ownership and control. To be consistent with our results on the sensitivities of the winner's prize to the size of the contestant pool and market volatility, we find that the performance effect of the winner's prize is greater for listed firms that are less controlled by the state.

The structure of the remaining part of the paper is as follows. In Section II, we present background information on the current Chinese corporate governance system. The empirical strategy and results are discussed in Section III, followed by the concluding section.

\section{State Ownership and Managerial Incentives}

${ }^{2}$ A most recent working paper by Conyon and He (2008) provides new evidence that less statecontrolled firms tend to provide their CEOs with greater equity incentives than more state-controlled firms. CEO incentives are found stronger in China's listed firms with less state control not only in cash compensation but also in equity ownership. 
Perhaps the most distinguishing feature of firms listed on China's stock exchanges is the predominance of state ownership and control. From their beginning in the early 1990s, the stock markets in Shanghai and Shenzhen were designed mainly to help state-owned enterprises (SOEs) raise capital and reduce their debt burden rather than to promote efficient resource allocation. To this end, quotas on public listings were imposed until 2000 and pubic listings were reserved almost exclusively for SOEs. The policy of "grasping the big and letting go of the small," adopted at the Chinese Communist Party's 15th Party Congress in 1997, vowed support for privatization of small SOEs and opened the door for ownership restructuring for large SOEs. However, ownership restructuring of Chinese listed firms has been sluggish. ${ }^{3}$ In 2003, the government remained the largest shareholder in over $80 \%$ of all listed firms. The state maintained control either by direct share ownership or by indirect ownership through legal person shares; together these holdings constitute about two thirds of the company stock of all listed firms. ${ }^{4}$

The preponderance of the state in China's listed firms implies the absence of adequate incentive mechanisms for managers to pursue economic efficiency. First, publicly-traded firms with strong state presence suffer from the separation between ownership by the general public and control by the bureaucrats in charge of the daily operations of the firm, who may have very different goals from the general public, as Shleifer and Vishny (1997) discuss. Second, even if the state is somewhat capable of holding the bureaucrats accountable for the state's goals, the multiple and oftentimes conflicting social objectives pursued by the state suggest that the firm's

\footnotetext{
${ }^{3}$ Naughton (1995) and Yang (1997) provide a detailed discussion on China's earlier enterprise reform from a historic perspective. Huang (2003) identifies the detrimental effects of China's delay in privatizing its SOEs. Megginson and Netter (2001) contains a general discussion on enterprise reform in transition economies.

${ }^{4}$ Unless noted otherwise, numbers cited are computed by the authors using the GTA and Sinofin data bases. Qiang (2003) provides similar estimates for different types of share percentages.
} 
economic efficiency is often sacrificed to achieve higher social goals, e.g., full employment. Third, state and legal-person shares of Chinese listed firms held directly or indirectly by the government are non-tradable and any transfer of these stocks must be approved by numerous government agencies, including both the CSRC and the Ministry of Finance. Hence, the disciplinary function of the market for corporate control is particularly weak for listed firms with the eminence of state control. Taken together, these characteristics weaken incentives for stateowned firms to pursue economic efficiency. ${ }^{5}$

To reflect such absence of adequate managerial incentive to pursue economic efficiency, most listed firms controlled by the state tend to follow the same procedures as SOEs concerning top personnel decisions. Depending on the level of authority over the firm, the government of the corresponding level appoints top management. For SOEs at the central government level, the central government's CCP (Communist Party of China) Department of Organization has the final say in the selection of the CEO or General Manager. For SOEs at the provincial government level, the Department of Organization at the provincial government makes these decisions. ${ }^{6}$ For listed firms that have the government or SOEs as their largest shareholders, the same procedures are apt to apply. According to China's Corporate Law, personnel decisions are supposed to be made by the board of directors. In reality, however, the candidates for the Chairman of the board of directors and the General Manager are almost always nominated by the largest government shareholder and rubber-stamped by the board. Thus, the multiplicity of the goals of the government points to the economic efficiency of the firm being often a secondary consideration to political pressures and social connections in personnel decisions.

\footnotetext{
${ }^{5}$ Bonin (1976), Weitzman (1976), Kornai (1992), Ickes and Samuelson (1987), Litwack (1991), and Dewatripont and Roland (1997) discuss the negative impact on managerial incentives of these arrangements.

${ }^{6}$ Our discussion of the personnel appointment process is based on surveys and interviews conducted in Beijing, Shanghai, and Chengdu, Sichuan in the summer of 2004.
} 
The relatively weak role of economic efficiency in personnel decisions in state-controlled listed firms is demonstrated most vividly in the determination of executive compensation. ${ }^{7}$ Before economic reform started in the late 1970s, executive compensation, as part of the rigid pre-reform compensation system, was mostly determined by the region, industry, level of management (by central or local government) and size of the enterprise, and job title, occupation, and seniority of the individual. Performance (either at the firm level or at the individual level), is typically not reflected in executive compensation.

In 1992 the CCP (Chinese Communist Party) accepted "a market economy with Chinese characteristics" as the goal of China's economic reform in general and a modern corporation system resembling Western corporations as the goal of SOE reform in particular. China's public policy makers appear to have recognized the importance of executive compensation as a key incentive device for top management and have considered it a crucial component of enterprise reform. Nevertheless, the effective implementation of such reform in China's listed firms appears to have been hampered by state ownership. First, new forms of executive compensation that are more reflective of firm performance and economic efficiency saw much faster adoption among privatized firms than among SOEs after it proved to be an effective incentive mechanism. According to a national survey conducted in 2002, the percentages of enterprises that had adopted such progressive compensation systems ranged from $15.2 \%$ for SOEs, to $20.2 \%$ for collective firms and $41.4 \%$ for privatized firms. ${ }^{8}$ Although a systematic study of managerial contracts is beyond the scope of this paper, both our interviews with firm executives and a review of several compensation plans used in these firms highlight the differences between how

\footnotetext{
${ }^{7}$ See Kato and Long (2006a) for detailed history of executive compensation reform.

${ }^{8}$ See "Report on Chinese Entrepreneurs: Emergence and Development"(Zhongguo qiyejia chengzhang yu fazhan baogao), p27, issued by the Survey System for Chinese Entrepreneurs 2004.
} 
SOEs and wholly privatized firms in China implement such compensation reform ${ }^{9}$

Most studies on Chinese listed firms provide evidence in support of the above notion that China's listed firms still controlled by the state tend to lack quality corporate governance. For instance, Lin (2001) argues that many listed firms are merely reincarnations of SOEs, which inherited both the inferior corporate governance and the poor firm performance. ${ }^{10}$ More recently, Kato and Long (2006a and 2006b) provide evidence linking poor corporate governance of China's listed firms more directly to state ownership and control by showing that the sensitivities of top executive compensation and turnover to firm performance are weaker in listed firms with greater proportion of stock owned by the state. In short, state-controlled listed firms tend to lack two important incentive mechanisms for top management which are most often discussed in the managerial incentive literature, pay-performance sensitivities and turnover-performance sensitivities. There is, however, one more potentially important incentive device for top management, promotion tournament. This paper will examine whether there is any evidence for the presence of well-functioning promotion tournament in China's listed firms and explore whether such promotion tournament is more or less likely to be present in listed firms with greater share of stock by the state.

\section{Empirical Strategy and Results}

Accounting and financial data as well as executive compensation data are obtained from

\footnotetext{
${ }^{9}$ Dong and Putterman (2003) provide empirical support for a similar argument explaining why state ownership slows down the interest alignment process between top managers and shareholders, namely that state-owned enterprises and thus their top executives in transition economies are often required to pursue non-financial objectives such as employment provision. For a more formal theoretical argument, see Schmidt and Schnitzer (1993).

${ }^{10}$ For a similar view, see Schipani and Liu (2001).
} 
the China Stock Market and Accounting Research Database (CSMAR) developed by Shenzhen GTA Information Technology Company, while ownership structure data are assembled from the database developed by SinoFin Information Services. The CSMAR data set has been used in previous studies, ${ }^{11}$ yet on our reading of the literature, we are one of the first to use the Sinofin dataset in academic research. Data are available annually for 1998 through 2002 although information is more complete for later years.

We use the Sinofin database to compute executive compensation including salary and bonus for two levels of top management: (i) level I consisting of top three highest-paid executives; and (ii) level II consisting of all other executives including all directors, supervisors, and high-level executives. ${ }^{12}$ The average compensation for level I executives (total compensation for level I, divided by three) was 110,062 in 1995 RMB whereas the average compensation for level II executives (total compensation for level II, divided by the total number of level II executives) was 79,212.26 in 1995 RMB. Following Eriksson (1999), we measure the prize of promotion tournament, PRIZE, by log of the ratio of the average compensation for level I executives to the average compensation for level II executives. We assume that level II executives are competing for promotion to level I positions. Reassuringly we confirm by studying the profiles of 50 randomly selected level-I executives that nearly all level-I executives were level-II executives in the same firm prior to promotion.

The cash prize for promotion to level I from level II in China's listed firms is on average about 40 percent increase in salary and bonus. The total prize may be larger, however, for equity

${ }^{11}$ See, for instance, Sun and Tong (2003), Bai, et. al. (2004), and Bai, Liu, and Song (2003).

${ }^{12}$ According to the rules from the CSRC (China Securities Regulatory Commission) that regulates the content of listed firms' annual reports, all listed firms have been required to report executive compensation including salary and bonus. Unfortunately they are not required to report salary and bonus separately and hence we are unable to analyze these two main components of cash compensation separately as Kato and Kubo (2003) did for their study of Japanese CEO compensation. 
ownership and perquisites (such as vehicle usage and housing subsidy) are usually linked to job titles and position ranks in the company. ${ }^{13}$

As presented in the previous section, we hypothesize that the well-functioning promotion tournament is still non-existent in Chinese listed firms that are owned and controlled by the state, whereas the efficient promotion tournament which generates adequate incentive for tournament contestants can be found in China's listed firms that are privatized. Specifically, we modify the empirical tournament model by Eriksson (1999) to reflect the important reality of Chinese listed firms (the continued ownership and control by the state for many listed firms in China). We then estimate the augmented tournament model using the aforementioned data:

$$
\begin{aligned}
\text { PRIZE }=\alpha+\beta \text { POOL }+\gamma \text { NOISE }+\delta \text { STATE } \\
\\
+\rho \text { POOL } * \text { STATE }+\tau \text { NOISE*STATE }+\boldsymbol{Z} \boldsymbol{\theta}+\mathbf{u}
\end{aligned}
$$

where POOL is the size of the tournament pool, measured by the total number of level-II executives; NOISE is the coefficient of variation of sale over the previous three years (a similar measure was used by Eriksson, 1999) ${ }^{14}$; STATE is the proportion of shares owned by the state (in percent); $\boldsymbol{Z}$ is a vector of control variables; $\alpha, \beta, \gamma, \delta, \rho$, and $\tau$ are the coefficients to be estimated; $\boldsymbol{\theta}$ is a column vector of coefficients on the control variables; and $\mathrm{u}$ is the disturbance term which we assume $\mathrm{u} \sim \operatorname{NID}\left(0, \sigma^{2}\right)$. For $\boldsymbol{Z}$, our data allow us to consider firm age, firm size (measured by log of sales), industry dummy variables, and year dummy variables which control for year-specific common macro shocks to all listed firms.

As shown in Eriksson (1999), we expect that tournament prize will rise with the size of contestant pool, for the probability of winning will fall as the number of contestants grows,

${ }^{13}$ Other types of executive perquisites in China include travel expenses, business gifts, and business attire expenses. These perks tend to have much lower values, according to our interviews with Chinese executives in the summer of 2004.

${ }^{14}$ As in the case of Eriksson (1999), we assume that the level of noise in individual manager's performance measure will be greater when the firm operates under more volatile market environment. 
which will in turn result in lower effort put forth by each contestant. To prevent the effort level from falling, the firm will need to increase the size of the winner's prize. We hypothesize that such an efficient response of the size of the prize to changes in the size of the contestant pool is more evident in China's listed firms that are less subject to state ownership and control, and hence more sensitive to economic performance. A negative and significant estimated coefficient on POOL*STATE supports the hypothesis.

Likewise the tournament winner will be decided on the contestant's observable relative performance measure. When the performance measure has more randomness (or is noisier), the tournament contestant feels he/she has less control over his/her performance and hence the ultimate winning of the tournament. In such a noisy environment, the contestant is less likely to exert much effort to win the tournament. To offset such an effort reduction due to an increase in noise, the firm will need to increase the winner's prize. As in the case of the sensitivity of the prize to the size of the contestant pool, we hypothesize that the sensitivity of the prize to noise will be greater for China's listed firms that are less subject to state ownership and control (or we expect the estimated coefficient on NOISE*STATE to be negative and significant).

Summary Statistics are provided in Table 1-1. The average size of the contestant pool (or the average number of level-II executives) during 1998-2002 was 11.2 and the coefficient of variation during the past three years was 0.25 . Sales revenue of the average listed firm was 1.1 billions of 1995-constant RMBs. The average age of China's listed firms was 4.9 years, reflecting the simple fact that listing of firms in China's stock exchanges started only recently.

Finally, data on ownership structure reveals that the public listing of SOEs in stock exchanges has not substantially reduced the dominance of state ownership. The average listed 
firm still has 58 percent of its company stock owned by the state. ${ }^{15}$

Table 1-2 presents the OLS estimates of Eq. (1). The estimated coefficient on POOL is positive and statistically significant at the 1 percent level, suggesting that tournament prize will increase significantly with the size of the contestant pool for fully privatized firms with $\mathrm{STATE}=0$. The estimated coefficient on an interaction term involving POOL and STATE is negative and statistically significant at the 1 percent level, supporting our hypothesis that the sensitivity of tournament prize to the size of the contestant pool is significantly lower for listed firms with a higher proportion of stocks owned by the state. Regarding NOISE, the estimated coefficient on NOISE itself is positive and almost statistically significant at the 10 percent level, suggesting that tournament prize needs to increase in order to compensate for the use of performance measure with greater noise at least for firms with STATE $=0$. As in the case of POOL, the estimated coefficient on an interaction term involving NOISE and STATE has an expected sign (negative) and is statistically significant at the 5 percent level, supporting our hypothesis that the sensitivity of tournament prize to noise is lower for listed firms with a higher proportion of stocks owned by the state.

To assess the magnitude of the effect of state ownership and control, we use the estimated coefficients and evaluate how the size of the tournament prize, PRIZE, will change when the size of the contestant pool increases from the $25^{\text {th }}$ percentile to the $75^{\text {th }}$ percentile. Most importantly we do so for four distinct levels of state ownership: (i) wholly state-owned (STATE=100); (ii) majority state-owned (STATE=50); (iii) one-quarter state-owned (STATE=25); and (iv) wholly private-owned (STATE=0). As shown in Table 2, on one hand for wholly state-owned firms, the winner's prize will change little even if the contestant pool increases considerably from the $25^{\text {th }}$

${ }^{15}$ To abstract from issues related to market segmentation, we excluded from our study the around $3 \%$ of Chinese corporate shares denominated in foreign currencies and available only to foreign investors, commonly referred to as B-shares. 
percentile to the $75^{\text {th }}$ percentile. For wholly privately-owned firms, on the other hand, the same increase of the contestant pool from the $25^{\text {th }}$ percentile to the $75^{\text {th }}$ percentile will result in a substantial increase in the winner's prize (tripling from 0.31 to 0.95 ). As expected, for onequarter state-owned firms, the prize will still increase rather substantially from 0.38 to 0.86 when the number of contestants rises from the $25^{\text {th }}$ to the $75^{\text {th }}$ percentile, although the sensitivity of the prize to the size of the contestant pool is not as large as for wholly privately-owned firms. The sensitivity of the winner's prize to the pool size further falls when we consider majority stateowned firms (the same increase in the pool size from the $25^{\text {th }}$ to the $75^{\text {th }}$ percentile resulting in an expansion of the prize from 0.48 to 0.60 ). For Chinese listed firms, ownership structure appears to still play a crucial role in shaping up internal managerial incentives and organizational efficiency.

Table 2 also shows similar yet much less pronounced results for NOISE. An increase in NOISE from the $25^{\text {th }}$ percentile to the $75^{\text {th }}$ percentile will result in a modest increase in the prize only for one quarter state-owned firms and wholly privately-owned firms (in fact, the increase in NOISE will lead to a fall in the prize for wholly state-owned firms and majority state-owed firms although the size of the fall is rather small). Admittedly our NOISE variable is quite indirect, requiring that noise in individual manager's performance measure is positively correlated with market volatility of firm performance. The less pronounced results for NOISE may be simply a refection of our less than perfect measure of noise in individual manager's performance.

Finally, to discern the strength of tournament incentives in China's listed firms, we estimate the effect on firm performance of the winner's prize. As we did earlier, we augment a performance equation of Eriksson (1999) by our state ownership variable (STATE):

(2) PERFORMANCE $=\alpha+\beta$ PRIZE $+\gamma$ STATE $+\delta$ PRIZE*STATE $+\boldsymbol{Z} \boldsymbol{\theta}+\mathbf{u}$ where PERFORMANCE is firm performance (measured by a variety of stock market 
performance measures as well as accounting performance measures); and $\mathbf{Z}$ is a vector of control variables; $\alpha, \beta, \gamma$, and $\delta$ are the coefficients to be estimated; $\theta$ is a column vector of coefficients on the control variables; and $\mathrm{u}$ is the disturbance term which we assume $\mathrm{u} \sim \operatorname{NID}\left(0, \sigma^{2}\right)$. For $\boldsymbol{Z}$, our data allow us to consider log of average managerial pay, industry dummy variables, and year dummy variables which control for year-specific common macro shocks to all listed firms.

The sign and significance of the estimated coefficient on PRIZE*STATE will indicate whether the performance effect of PRIZE is greater or smaller for China's listed firms with less control of the state.

As shown in Table 3-1, the data allow us to consider five firm performance measures. There are two standard stock market performance measures; (i) industry adjusted stock return or RETURN; and (ii) annual change in shareholder value of the firm or $\triangle$ VALUE. In addition, there are three standard accounting profitability measures; (i) industry adjusted return on asset or ROA; (ii) annual change in ROA or $\triangle \mathrm{ROA}$; and (iii) incidence of negative profit or NEGATIVE PROFIT $=1$ if the firm's profit is negative, 0 otherwise (Kato and Long, 2006). ${ }^{16}$ The summary table indicates that the average industry and inflation adjusted annual stock return over the sample period was 3.6 percent and that the average firm increased its shareholder value by $64,500,000$ RMB per year. Furthermore, regarding accounting profitability, the average industry adjusted annual ROA over the sample period was a little over 1 percent with the average annual change of negative 0.8 percentage-points; and almost 9 percent of firms showed negative profit over the sample period.

The OLS estimates of Eq. (2) are summarized in Table 3-2. When RETURN is used to measure firm performance, the estimated coefficient on PRIZE is positive and statistically

\footnotetext{
${ }^{16}$ We also considered profit margin (profit/sales) instead of ROA and found similar results. These as well as all other unreported results are available from the authors upon request.
} 
significant at the 1 percent level, suggesting that for wholly privately owned listed firms in China, firms offering greater prize for the promotion tournament winner tend to enjoy higher stock return than other firms. The estimated coefficient on PRIZE*STATE is, however, negative and statistically significant at the 1 percent level, confirming our expectation that the performance effect of PRIZE is smaller for firms that are still strongly controlled by the state. The relative size of the estimated coefficient on PRIZE to the one on PRIZE*STATE implies that the performance effect of PRIZE continues to fall as the proportion of shares owned by the state rises and that it is actually zero for listed firms that are majority-owned by the state.

The table also shows the results are robust to the use of an alternative stock market performance measure, $\triangle$ VALUE with the positive and highly significant coefficient on PRIZE and the negative and highly significant coefficient on PRIZE*STATE. To be consistent with Kato and Long (2006) showing the relative importance of stock market measures to accounting performance measures in pay-performance sensitivities, we also find less significant association between PRIZE and accounting profitability measures although the estimated coefficients on PRIZE and STATE*PRIZE are of expected signs.

\section{Concluding Remarks}

The promotion tournament as a potentially important incentive mechanism for top management in transition economies has not been examined by the emerging literature on managerial incentives in transition economies. This paper is the first attempt to fill this important gap in the literature. The paper has begun with modifying the previously-derived empirical predictions from the tournament theory to the context of transition economies in which state ownership still plays a significant role in listed firms. Specifically, we have tested two 
hypotheses: (i) the sensitivity of the winner's prize to the size of the contestant pool is greater for listed firms that are less owned and controlled by the state; and (ii) the sensitivity of the winner's prize to noise in performance measure used to determine the tournament winner is also greater for such less state-owned listed firms. Using comprehensive financial and accounting data on China's listed firms from 1998 to 2002, augmented by unique data on executive compensation and ownership structure, we have found evidence in support of both hypotheses. The winner's prize will need to increase in order to prevent each contestant from lowering his/her effort level in the face of expanding contestant pool. Such an optimal response of the winner's prize to the size of the contestant pool has been found to be more evident for China's listed firms that are less owned and controlled by the state. Likewise, the winner's prize will also need to rise in order to prevent each contestant from reducing his/her effort level when faced with rising noise in performance measure that is used to decide on the tournament winner. Again, we have found that such an efficient response of the prize to noise does not occur for China's listed firms insofar as they are still majority state-owned.

Finally, we have also found evidence suggesting that an increase in the winner's prize will result in enhanced managerial effort and hence improved firm performance, and that the performance effect of the winner's prize is greater for China's listed firms that are less controlled by the state.

As such, we have provided yet another piece of evidence that ownership restructuring may be needed for China to successfully transform its SOEs to efficient modernized corporations and reform its overall economy. 
Table 1-1 The Effect on PRIZE of POOL and NOISE: Summary Statistics

\begin{tabular}{|l|r|r|r|}
\hline Variable & \multicolumn{1}{|c|}{ Mean } & \multicolumn{1}{l|}{ s.d. } & N \\
\hline $\ln ($ PRIZE) & 0.270 & 0.339 & 3158 \\
\hline POOL & 11.159 & 4.528 & 3158 \\
\hline NOISE & 0.250 & 0.206 & 3158 \\
\hline STATE & 58.118 & 13.448 & 3158 \\
\hline $\ln ($ SALE $)$ & 20.039 & 1.277 & 3158 \\
\hline FIRMAGE & 4.885 & 2.612 & 3158 \\
\hline
\end{tabular}

Sources: Accounting and financial data are from the China Stock Market and Accounting Research Database (CSMAR) developed by Shenzhen GTA Information Technology Company. Data on executive compensation are from the database developed by Sinofin Information Services.

Note: The data are based on a pooled cross-sectional time series dataset on 923 listed firms. SALE is measured in RMB and adjusted for inflation using the CPI with 1995 as the base year.

Table 1-2 The Effect on PRIZE of POOL and NOISE: Summary Statistics: OLS Estimates Dependent variable $=$ PRIZE

\begin{tabular}{|l|r|l|}
\hline $\begin{array}{l}\text { Independent } \\
\text { variable }\end{array}$ & $\begin{array}{r}\text { Estimated } \\
\text { coefficient }\end{array}$ & $\begin{array}{l}\text { Standard } \\
\text { error }\end{array}$ \\
\hline POOL & $0.045 \quad * * *$ & 0.006 \\
\hline NOISE & $0.191 \quad$ & 0.118 \\
\hline STATE & $0.006 \quad * * *$ & 0.001 \\
\hline POOL*STATE & $-0.00426 * * *$ & 0.00011 \\
\hline NOISE*STATE & $-0.004 * *$ & 0.002 \\
\hline $\ln ($ SALE) & $0.009 *$ & 0.005 \\
\hline FIRMAGE & $-0.012 *$ & 0.007 \\
\hline Observations & \multicolumn{3}{|c|}{3158} \\
\hline R-squared & \multicolumn{3}{|c|}{0.166} \\
\hline
\end{tabular}

Sources: Accounting and financial data are from the China Stock Market and Accounting Research Database (CSMAR) developed by Shenzhen GTA Information Technology Company. Data on executive compensation are from the database developed by Sinofin Information Services.

Note: The data are based on a pooled cross-sectional time series dataset on 923 listed firms. All value variables are measured in RMB and adjusted for inflation using the CPI with 1995 as the base year. All models include constant term, industry dummy variables and year dummy variables.

*** significant at the 1 percent level

** significant at the 5 percent level

* significant at the 10 percent level 
Table 2 The Size of the Effect on PRIZE of POOL and NOISE with different levels of STATE

\begin{tabular}{|l|l|r|r|r|r|}
\hline \multicolumn{2}{|l|}{} & POOL $=25$ th & POOL=75th & NOISE=25th & NOISE=75th \\
\hline STATE $=100$ & PRIZE & 0.567 & 0.577 & 0.594 & 0.538 \\
\hline STATE $=50$ & PRIZE & 0.482 & 0.600 & 0.532 & 0.525 \\
\hline STATE $=25$ & PRIZE & 0.376 & 0.855 & 0.501 & 0.519 \\
\hline STATE $=0$ & PRIZE & 0.318 & 0.948 & 0.470 & 0.513 \\
\hline
\end{tabular}

Sources: Accounting and financial data are from the China Stock Market and Accounting Research Database (CSMAR) developed by Shenzhen GTA Information Technology Company. Data on executive compensation are from the database developed by Sinofin Information Services.

Note: Based on the estimated coefficients in Table 2.

Table 3-1 Firm Performance and PRIZE: Summary Statistics

\begin{tabular}{|l|r|r|r|}
\hline Variable & Mean & s.d. & $\mathrm{N}$ \\
\hline RETURN & .0364357 & .1871855 & 2594 \\
\hline$\Delta$ VALUE & $6.45 \mathrm{e}+07$ & $7.36 \mathrm{e}+08$ & 2341 \\
\hline ROA & .0109185 & .1635432 & 2627 \\
\hline$\Delta$ ROA & -.0080075 & .1658523 & 2347 \\
\hline $\begin{array}{l}\text { NEGATIVE } \\
\text { PROFIT }\end{array}$ & .0898363 & .2860016 & 2627 \\
\hline $\ln ($ PAY) & 11.03733 & .8152924 & 2627 \\
\hline
\end{tabular}

Sources: Accounting and financial data are from the China Stock Market and Accounting Research Database (CSMAR) developed by Shenzhen GTA Information Technology Company. Data on executive compensation are from the database developed by Sinofin Information Services.

Note: The data are based on a pooled cross-sectional time series dataset on 835 listed firms. All variables except for NEGATIVE PROFIT ( $=1$ if the firm's profit is negative, 0 otherwise) are measured in RMB and adjusted for inflation using the CPI with 1995 as the base year. 
Table 3-2 Firm Performance and PRIZE: OLS Estimates

\begin{tabular}{|l|l|l|l|l|l|}
\hline \multirow{2}{*}{} & \multicolumn{5}{|c|}{ Dependent variable= } \\
\cline { 2 - 6 } & RETURN & $\Delta$ VALUE & ROA & $\Delta$ ROA & $\begin{array}{l}\text { NEGATIVE } \\
\text { PROFIT }\end{array}$ \\
\hline PRIZE & $0.160^{* * *}$ & $5.447 \mathrm{e}+08^{* * *}$ & 0.058 & 0.021 & $-0.143^{*}$ \\
\hline & $(0.054)$ & $(206100000.000)$ & $(0.047)$ & $(0.050)$ & $(0.081)$ \\
\hline STATE & $0.001^{*}$ & $8027957.797^{* * *}$ & $4.09 \mathrm{e}-4$ & $5.14 \mathrm{e}-4$ & $-0.002^{* *}$ \\
\hline & $(0.000)$ & $(1630443.457)$ & $(3.67 \mathrm{e}-4)$ & $(3.99 \mathrm{e}-4)$ & $(0.001)$ \\
\hline PRIZE*STATE & $-0.003^{* * *}$ & $-9532690.544^{* * *}$ & $-2.32 \mathrm{e}-4$ & $-3.39 \mathrm{e}-5$ & 0.001 \\
\hline & $(0.001)$ & $(3482477.033)$ & $(7.82 \mathrm{e}-4)$ & $(8.51 \mathrm{e}-4)$ & $(0.001)$ \\
\hline $\ln ($ PAY) & $0.026^{* * *}$ & $96136536.934^{* * *}$ & $0.015^{* * *}$ & $4.41 \mathrm{e}-4$ & $-0.068^{* * *}$ \\
\hline & $(0.005)$ & $(21208179.628)$ & $(0.005)$ & $(5.18 \mathrm{e}-3)$ & $(0.008)$ \\
\hline Observations & 2594 & 2341 & 2627 & 2347 & 2627 \\
\hline R-squared & 0.09 & 0.18 & 0.09 & 0.04 & 0.11 \\
\hline Sources:
\end{tabular}

Sources: Accounting and financial data are from the China Stock Market and Accounting Research Database (CSMAR) developed by Shenzhen GTA Information Technology Company. Data on executive compensation are from the database developed by Sinofin Information Services.

Note: The data are based on a pooled cross-sectional time series dataset on 835 listed firms. All variables except for STATE and NEGATIVE PROFIT $(=1$ if the firm's profit is negative, 0 otherwise) are measured in RMB and adjusted for inflation using the CPI with 1995 as the base year. All models include constant term, industry dummy variables and year dummy variables.

*** significant at the 1 percent level

** significant at the 5 percent level

* significant at the 10 percent level 
References

Aghion, Philippe; Blanchard, Olivier Jean and Burgess, Robin. "The Behaviour of State Firms in Eastern Europe, Pre-Privatisation." European Economic Review, 1994, 38(6), pp. 1327-49.

Agrawal, Anup; Knoeber, Charles R. and Tsoulouhas, Theofanis. "Are Outsiders Handicapped in CEO Successions?" Journal of Corporate Finance, 2006, 12(3), pp. 61944.

Audas, Rick; Barmby, Tim and Treble, John. "Luck, Effort, and Reward in an Organizational Hierarchy." Journal of Labor Economics, 2004, 22(2), pp. 379-95.

Bai, Chong-En; Liu, Qiao; Lu, Joe; Song, Frank M. and Zhang, Junxi. "Corporate Governance and Market Valuation in China." Journal of Comparative Economics, 2004, 32(4), pp. 599-616.

Bai, Chong-en; Liu, Qiao and Song, Frank M. "The Value of Private Benefits: Evidence from an Emerging Market for Corporate Control," Working Paper, University of Hong Kong, Hong Kong, 2003.

Baker, George; Gibbs, Michael and Holmstrom, Bengt. "The Wage Policy of a Firm." Quarterly Journal of Economics, 1994, 109(4), pp. 921-55.

Bebchuk, Lucian Arye. "A Rent-Protection Theory of Corporate Ownership and Control," NBER Working Papers No.7203, National Bureau of Economic Research, Cambridge, MA, 1999.

Bognanno, Michael L. "Corporate Tournaments." Journal of Labor Economics, 2001, 19(2), pp. 290-315.

Bonin, John P. "On the Design of Managerial Incentive Structures in a Decentralized Planning Environment." American Economic Review, 1976, 66(4), pp. 682-87.

Claessens, Stijn and Djankov, Simeon. Manager Incentives and Turnover of Managers: Evidence from the Czech Republic. New York/London: St. Martin's Press, Macmillan Press, 2000.

Conyon, Martin J. and He, Lerong. "Executive Compensation and CEO Equity Incentives in China's Listed Firms," ESSEC Business School, 2008.

Dewatripont, Mathias and Roland, Gerard. "Transition as a Process of Large-Scale Institutional Change," D. M. Kreps and K. F. Wallis, Advances in Economics and Econometrics: Theory and Applications: Seventh World Congress, Volume 2. Cambridge/New York/Melbourne: Cambridge University Press, 1997, 240-78.

Dong, Xiao-Yuan and Putterman, Louis. "Soft Budget Constraints, Social Burdens, and Labor Redundancy in China's State Industry." Journal of Comparative Economics, 2003, 31(1), pp. 110-33.

Drago, Robert and Garvey, Gerald T. "Incentives for Helping on the Job: Theory and Evidence." Journal of Labor Economics, 1998, 16(1), pp. 1-25.

Ehrenberg, Ronald G. and Bognanno, Michael L. "Do Tournaments Have Incentive Effects?" Journal of Political Economy, 1990, 98(6), pp. 1307-24.

Eriksson, Tor. "Executive Compensation and Tournament Theory: Empirical Tests on Danish Data." Journal of Labor Economics, 1999, 17(2), pp. 262-80.

. "Managerial Pay and Executive Turnover in the Czech and Slovak Republics." Economics of Transition, 2005, 13(4), pp. 659-77.

Gibson, Michael S. "Is Corporate Governance Ineffective in Emerging Markets?" Journal of Financial and Quantitative Analysis, 2003, 38(1), pp. 231-50. 
Huang, Yasheng. Selling China: Foreign Direct Investment during the Reform Era. Cambridge; New York and Melbourne: Cambridge University Press, 2003.

Ickes, Barry W. and Samuelson, Larry. "Job Transfers and Incentives in Complex Organizations: Thwarting the Ratchet Effect." RAND Journal of Economics, 1987, 18(2), pp. 275-86.

Jefferson, Gary H.; Su, Jian; Yuan, Jiang and Xinhua, Yu. "The Impact of Shareholding Reform on Chinese Enterprise Performance, 1995-2001," J. Nellis and N. Birdsall, Reality Check: Assessing the Distributional Impact of Privatization. Washington, D.C., forthcoming: Center for Global Development, 2004,

Jones, Derek C. and Kato, Takao. "The Determinants of Chief Executive Compensation in Transitional Economies: Evidence Form Bulgaria." Labour Economics, 1996, 3(3), pp. 319-36.

Jones, Derek C. and Mygind, Niels. "Majority Ownership and Executive Compensation," 2004 ASSA Meetings, San Diego, January 3-5. 2004.

Kato, Takao and Kubo, Katsuyuki. "CEO Compensation and Firm Performance in Japan: Evidence from New Panel Data on Individual CEO Pay." Journal of the Japanese and International Economies, 2006, 20(1), pp. 1-19.

Kato, Takao and Long, Cheryl. "CEO Turnover, Firm Performance, and Enterprise Reform in China: Evidence from Micro Data." Journal of Comparative Economics, 2006, 34(4), pp. 796-817.

- "Executive Compensation, Firm Performance, and Corporate Governance in China: Evidence from Firms Listed in the Shanghai and Shenzhen Stock Exchanges." Economic Development and Cultural Change, 2006, 54(4), pp. 945-83.

. "Executive Turnover and Firm Performance in China." American Economic Review, 2006, 96(2), pp. 363-67.

Knoeber, Charles R. and Thurman, Walter N. "Testing the Theory of Tournaments: An Empirical Analysis of Broiler Production." Journal of Labor Economics, 1994, 12(2), pp. 155-79.

Kornai, Janos. The Socialist System: The Political Economy of Communism. Princeton: Princeton University Press, 1992.

Lambert, Richard A.; Larcker, David F. and Weigelt, Keith. "The Structure of Organizational Incentives." Administrative Science Quarterly, 1993, 38, pp. 438-61.

Lazear, Edward P. and Rosen, Sherwin. "Rank-Order Tournaments as Optimum Labor Contracts." Journal of Political Economy, 1981, 89(5), pp. 841-64.

Lin, Cyril. "Corporatisation and Corporate Governance in China's Economic Transition." Economics of Planning, 2001, 34(1-2), pp. 5-35.

Litwack, John M. "Legality and Market Reform in Soviet-Type Economies." Journal of Economic Perspectives, 1991, 5(4), pp. 77-89.

Main, Brian G. M.; O'Reilly, Charles A., III and Wade, James. "Top Executive Pay: Tournament or Teamwork?" Journal of Labor Economics, 1993, 11(4), pp. 606-28.

Megginson, William L. and Netter, Jeffry M. "From State to Market: A Survey of Empirical Studies on Privatization." Journal of Economic Literature, 2001, 39(2), pp. 321-89.

Muravyev, Alexander. "Turnover of Senior Managers in Russian Privatised Firms." Comparative Economic Studies, 2003, 45(2), pp. 148-72.

O'Reilly III, Charles A.; Main, Brian G. and Crystal, Graef S. "CEO Compensation as Tournament and Social Comparison: A Tale of Two Theories." Administrative Science 
Quarterly, 1988, 33(2), pp. 257.

Qiang, Qu. "Corporate Governance and State-Owned Shares in China Listed Companies." Journal of Asian Economics, 2003, 14(5), pp. 771-83.

Schipani, Cindy A. and Junhai, Liu. "Corporate Governance in China: Then and Now." William Davidson Institute Working Paper no. 407, University of Michigan, 2001.

Schmidt, Klaus M. and Schnitzer, Monika. "Privatization and Management Incentives in the Transition Period in Eastern Europe." Journal of Comparative Economics, 1993, 17(2), pp. 264-87.

Shleifer, Andrei and Vishny, Robert W. "A Survey of Corporate Governance." Journal of Finance, 1997, 52(2), pp. 737-83.

Sun, Qian and Tong, Wilson H. S. "China Share Issue Privatization: The Extent of Its Success." Journal of Financial Economics, 2003, 70(2), pp. 183-222.

Weitzman, Martin L. "The New Soviet Incentive Model," Bell Journal of Economics. 1976, 251-57.

Yang, Qixian. "SOE Reforms and Institutional Renovations," F. Dong, Y. Li and Z. Han, The Future Road of State Owned Enterprises. Beijing, P.R. China: Economic Science Publishing, 1997, 30-52. 